\title{
火打山ライチョウを事例とした高山帯の市民参加型調査に参加意思を有する登山者の特徴
}

\section{Attributes of Potential Participants for Citizen-based Monitoring for Alpine Zone in a case study of Rock Ptarmigan Survey at Mt. Hiuchi}

\author{
武 正憲* 小川 結衣** 佐方 啓介*** \\ Masanori TAKE Yui OGAWA Keisuke SAKATA
}

\begin{abstract}
The citizen science is paid attention as an effective approach to study the number of wildlife. However, it is not easy to collect participants in such survey. The objective of this study is to clarify the characterization of potential participants among climbers who took part in Hiuchisan, Nihon Raicho (Japanese rock ptarmigan) survey tour. We conducted survey against climbers and obtained 393 responds. Depending on intention of participation of the tour, we could divide target group into two groups. Then we analyze to confirm the difference of such groups. The climbers' characteristics were depending on climbing history, knowledge of target, experience of environmental conservation activities. At the participant recruitment, it was suggested the necessity to consider characterization of climber's profile.
\end{abstract}

Keywords: citizen science, mountaineer, questionnaire survey, alpine zone キーワード：市民参加型調査, 登山者, アンケート調査, 高山帯

\section{1. はじめに}

生物多様性国家戦略 2012-2020 の達成には, 様々な自然環境で の市民参加型のモニタリング調查 (以下, 市民参加型調査と記す) 実施が求められるとされる 1)。しかし，市民参加型調査の実施地 はアクセスのよい場所に限定されてきた。例えば，日本を代表す る市民参加型調査の一つである重要生態系監視地域モニタリング 推進事業（以下，モニタリングサイト 1000 と記す）では，調査 地の選定条件として，車道やロープウェイ等が整備されていると いった, 徒歩以外のアクセス手段があることと規定されている2)。 アクセスが容易でない地域での市民参加型調査を推進させるた めに，本研究では，特に高山帯に着目した。高山帯は，基本的に は徒歩以外のアクセス手段がない地域であるが，レクリエーショ ンの場として登山者が好んで利用寸る。したがって，高山帯は登 山者が参加者となる市民参加型調查実施の潜在性が高い地域と言 え, アクセスの困難な場所であっても市民参加型調査がより推進 される可能性が考えられる。

高山帯で市民参加型調査を推進させるための課題の一つとして, 参加者確保が挙げられる。市民参加型調査で専門家による調査を 補うことのできる参加者を確保するには，高度な技術を要さない 調査の場合, 調査への参加意思がある人から募集することが有効 とされる 3)。また，調査への参加につながるような，保護活動へ の市民の参加意欲の解明を試みた研究も存在する。本田は, ツシ マヤマネコの保護活動に参加意思がある人の特徵から，若年層が 参加しやすい形式での保護活動の展開や，女性を対象に参加者を 募集することを提唱した ${ }^{4)}$ 。また，高瀬ら 5)は，緑地保全活動団 体と活動経験者でない市民の保全活動への意識差から，活動への 参加に結びつけるためには, 年齢層に応じて団体の活動に関する 魅力発信方法を変える必要性があるとしている。このように，活 動に参加意思のある人の特徵をもとに，参加者の募集方法を検討 した研究は存在する。しかし，高山带では，急傾斜や徒歩に限ら れるアクセス手段などの山岳地特有の要素から，これまで報告さ
れてきた市民参加型調査への参加意思を有する人の特徵がそのま ま応用できるとは限らない。そこで本研究は，高山帯に生息する 絶滅伦惧種ライチョウを対象とした市民参加型調查を事例とし, 調査ツアーに参加意思を有する登山者と有さない登山者とを比較 することで, 参加意思を有する登山者の特徵を明らかにすること を目的とする。

\section{2. 研究の方法}

\section{(1) 研究対象}

本研究では，生息地へのアクセスが容易でなくても，その保全 のために生息情報の収集が必要であることから, すでに市民参加 型調査が実施されているライチョウ 6)に注目した。ライチョウは 標高 2,000〜2,400m 以上の高山帯にのみ生息している。環境省レ ッドリスト絶减伦惧 I B 類に指定されており, 保護増殖事業の対 象種である 7)。

研究対象地は, 登山ツアーによるライチョウの市民参加型調査 (以下，調査ツアーと記す）と，ライチョウ調查専門家による調 查地が重なる場所である，新潟県妙高市と糸魚川市にまたがる頸 城山塊の火打山 $(2,462 \mathrm{~m})$ とした (図-1)。火打山は, 妙高戸隠 連山国立公園内に存在し，山頂付近などは特別保護地区に指定さ れている。火打山は, 山頂付近から北方向, 東方向, 西方向に比 較的なだらかな尾 根が 3 つ伸びてい るが，山頂部や尾 根筋を除くと，多 くの場所は急峻な 地形である 8 。

火打山では, ラ イチョウ調査専門 家による調査が 2007 年から年 2

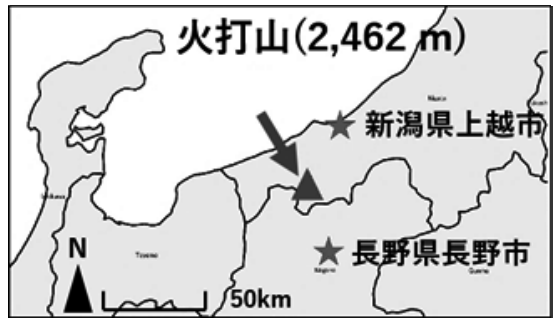

図-1 火打山の位置図

*筑波大学芸術系, **元筑波大学大学院生命環境科学研究科, ***筑波大学生命環境系 
～3 回程度の頻度で継続されている。しかし，笹ヶ峰登山口 $(1,300 \mathrm{~m})$ からライチョウの生息地である高山帯の調査エリア入 口付近（雷鳥平 $2,235 \mathrm{~m}$ ）までのアクセスは，標高差 $935 \mathrm{~m}$ 片道 4 時間半程度の登山が必要で，専門家にとっても容易ではない。 したがって, 調查活動ができる時間, 頻度, 区域等には限界があ り，十分な数の調査実施はできていない9)。このような課題を解 決するため，調査時間，頻度，地域等の不足を補うための仕組み の一つとして, 調査ツアーを 2013 年から火打山で実施している 10)

\section{（2）方法}

\section{1）アンケート調査}

高山帯における市民参加型調査に参加意思を有寸る登山者とそ うでない登山者の特徴を比較するために，火打山から下山した登 山者を対象に，笹ヶ峰登山口にてアンケート調査を行った。笹ケ 峰登山口では，火打山のほかにも妙高山や焼山などへの登山，散 策，釣り等の利用も存在するが，調査対象者は火打山から下山し た登山者のみに限定した。アンケート調査を行う時期は，ライチ ヨウの個体発見機会がもつとも多い時期である 5 月 (残雪期), 火打山での登山者数がピークを迎える 7 月（夏山期），これまで に調査ツアーが実施され，今後も調査ツアーを開催する可能性の ある時期である 10 月（紅葉期）とした。調査日は 2017 年 5 月 13 日〜 14 日， 7 月 7 日〜 9 日， 10 月 7 日〜 $~ 9$ 日の合計 8 日間と した。

質問項目は, 先行研究 5)1112)13)を参照し, 先行研究において保全 活動への参加意思がある人の特徵として抽出されている項目に加 え, 高山帯における市民参加型調査の参加者募集の際に有益と考 えられる情報を項目とした。具体的には，1．基本属性，2．登山 に関する質問，3．環境保全活動経験の有無，4. ライチョウ目撃 経験の有無，5. ライチョウとの能動的な関わりの有無，6.ライチ ヨウに関する認知の有無, 7. 調査ツアーへの参加意思の有無で ある。1. 基本属性は，年代，性別，居住地（笹ヶ峰登山口から $50 \mathrm{~km}$ 以内の地域に居住かどうか)，収入を質問した。2. 登山に 関する質問は，登山歴，年間の登山頻度を聞くものとした。3. 環境保全活動経験は，アンケート調査票のなかで, 先行研究 5) を 参考に「環境保全活動とは，公園や樹林，農地，河川，山岳地等 における，草刈り，植林，樹木の剪定，清掃活動，農作業体験， 自然教室, 動植物の調査, 外来生物の除去, 登山道整備などの活 動です。と説明した上で，その有無を聞いた。5. ライチョウと の能動的関わりとしては, ライチョウに関する講演会に参加した, 調査講習会に参加した，WEBサイト・SNS などで情報をチェッ クした，書籍を読んだ，グッズを持っている，の5つとし，有無 を聞いた。なお，回答結果に対し一つでも「有」と回答した人は 能動的な関わりが有る者とした。6. ライチョウに関する知識の 有無に関しては，ライチョウが絶滅危惧種であることの認知，火 打山にライチョウが生息していることの認知, 火打山のライチョ ウが最小の個体群であることの認知の 3 つした。7. 調査ツア 一への参加の有無については，調査ツア一内容を記した資料を見 せた上で，その内容を事前に説明した。

2) 分析方法

まず，回答者の回答傾向を把握するため，選択肢ごとに何人が 回答しているかを把握した。次に, 調査ツアーへの参加意思の「有」

「無」によって被験者をふたつのグループに分け，グループの違 いがその他の質問項目の回答傾向に関係するかを $\chi^{2}$ 検定によっ て確認した。 $\chi^{2}$ 検定において期待度数が 5 以下の場合は Fisher の正確確率検定を実施した。さらに， $\chi^{2}$ 検定で有意差が認められ た質問項目は，残差分析によりどの選択肢の影響によるものかを 確認した。有意水準は $5 \%$ とした。なお，統計解析は IBM SPSS Statistics24 を用いた。

\section{表ー1 アンケート結果の概要}

\begin{tabular}{|c|c|c|c|}
\hline & & 人数 & 割合 \\
\hline 回答時期と & 5月(残雪期) & 30 & $7.6 \%$ \\
\hline \multirow{3}{*}{ 有効回答者数 } & 7月(夏山期) & 137 & $34.9 \%$ \\
\hline & 10月(紅葉期) & $\underline{\underline{266}}$ & $57.5 \%$ \\
\hline & 合計 & 393 & \\
\hline \multicolumn{4}{|l|}{ 1. 基本属性 } \\
\hline \multirow[t]{8}{*}{ 1) 年代 } & 10 代 & 4 & $1.0 \%$ \\
\hline & 20 代 & 26 & $6.6 \%$ \\
\hline & 30 代 & 61 & $15.5 \%$ \\
\hline & 40 代 & $\underline{96}$ & $\underline{24.4 \%}$ \\
\hline & 50 代 & 97 & $247 \%$ \\
\hline & 60 代 & 86 & $21.9 \%$ \\
\hline & 70 代 & 21 & $5.3 \%$ \\
\hline & 未回答 & 2 & $0.5 \%$ \\
\hline \multirow{3}{*}{ 2) 性別 } & 男性 & $\underline{289}$ & $73.5 \%$ \\
\hline & 女性 & 104 & $26.5 \%$ \\
\hline & 合計 & 393 & \\
\hline \multirow[t]{2}{*}{ 3) 居住地 } & 近隣 (新潟、長野、群馬、富山) & 186 & $47.3 \%$ \\
\hline & その他 & 207 & $52.7 \%$ \\
\hline \multirow[t]{3}{*}{ 4）配偶者 } & 直 & 261 & $66.4 \%$ \\
\hline & 無 & 129 & $32.8 \%$ \\
\hline & 未回答 & 3 & $0.8 \%$ \\
\hline \multirow[t]{6}{*}{ 5) 収入 } & 200万円未満 & 16 & $4.1 \%$ \\
\hline & 200万円以上，400万円未満 & $\underline{84}$ & $21.4 \%$ \\
\hline & 400万円以上, 600 万円未満 & $\underline{\underline{96}}$ & $24.4 \%$ \\
\hline & 600万田以上，800万田未満 & 67 & $17.0 \%$ \\
\hline & 800万田以上 & 82 & $20.9 \%$ \\
\hline & 未回答 & 48 & $12.2 \%$ \\
\hline \multicolumn{4}{|l|}{ 2. 登山経験 } \\
\hline \multirow[t]{7}{*}{ 1) 登山歴 } & 1年未満 & 10 & $2.5 \%$ \\
\hline & 1２年 & 23 & $5.9 \%$ \\
\hline & $3 \sim 4$ 年 & 52 & $13.2 \%$ \\
\hline & $5 \sim 10$ 年 & $\underline{\underline{138}}$ & $3.1 \%$ \\
\hline & 11２0年 & 61 & $15.5 \%$ \\
\hline & 21年以上 & 107 & $\underline{27.2 \%}$ \\
\hline & 未回答 & 2 & $0.5 \%$ \\
\hline \multirow[t]{6}{*}{ 2) 1年の登山頻度 } & 1回以下 & 10 & $2.5 \%$ \\
\hline & 2 3回程度 & 60 & $15.3 \%$ \\
\hline & 4〜 5回程度 & 72 & $18.3 \%$ \\
\hline & 6 10回程度 & $\underline{86}$ & $\underline{21.9 \%}$ \\
\hline & 10回以上 & $\underline{\underline{163}}$ & $41.5 \%$ \\
\hline & 未回答 & 2 & $0.5 \%$ \\
\hline
\end{tabular}
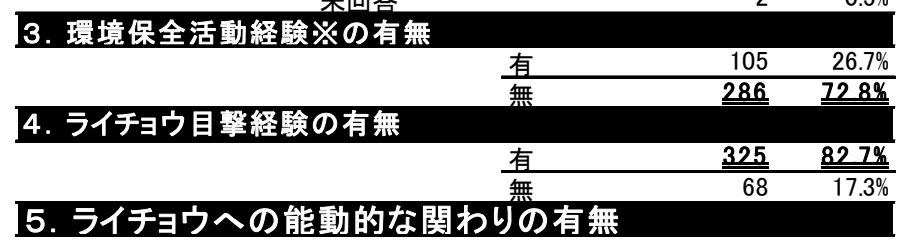

\begin{tabular}{|c|c|c|c|}
\hline \multirow[t]{2}{*}{ 1)講演会に参加したことがある } & 直 & 13 & 3.3 \\
\hline & $\begin{array}{l}\text { 無 } \\
\end{array}$ & 380 & 967 \\
\hline \multirow{2}{*}{$\begin{array}{l}\text { 2) 調査講習会に参加した } \\
\text { こがある }\end{array}$} & 直 & 6 & 1. \\
\hline & \begin{tabular}{|c|c|} 
無 \\
\end{tabular} & 387 & 98.5 \\
\hline \multirow{2}{*}{$\begin{array}{l}\text { 3)WEBサイト, SNSなどで情報を } \\
\text { チェックしたことがある }\end{array}$} & 直 & $\overline{444}$ & \\
\hline & $\begin{array}{l}\text { 無 } \\
\end{array}$ & 349 & 88.8 \\
\hline \multirow{2}{*}{ 4)書籍を読んだことがある } & 直 & 62 & 15. \\
\hline & $\begin{array}{l}\text { 無 } \\
\end{array}$ & $\underline{331}$ & 842 \\
\hline \multirow{2}{*}{ 5)グッズを持っている } & 直 & 26 & \\
\hline & $\begin{array}{l}\text { 無 } \\
\end{array}$ & 367 & $\underline{\underline{93}}$ \\
\hline \multirow{2}{*}{$\begin{array}{l}\text { 上記1)〜5)のいずれかの } \\
\text { 関わりの有無 } \\
\text { ライチョウ関する知識 }\end{array}$} & 直 & $\overline{102}$ & 26. \\
\hline & $\begin{array}{l}\text { 無 } \\
\end{array}$ & 291 & 4 \\
\hline
\end{tabular}

\section{6. ライチョウに関する知識}

1)ライチョウが絶滅危惧種で

あることの認知

2)ライチョウが火打山に生息

していることの認知

3) 火打山のライチョウ個体群が国

内最小集団であることの認知

7. 調查ツアーへの参加意思

\begin{tabular}{|c|c|c|}
\hline 知っている & $\underline{\underline{353}}$ & $\underline{\underline{8}}$ \\
\hline 知らない & $\overline{40}$ & $\overline{10}$ \\
\hline 知っている & $\underline{\underline{285}}$ & $\underline{725}$ \\
\hline 知らない & 108 & 27 \\
\hline 知っている & 123 & 31. \\
\hline 知らない & 270 & 68 \\
\hline 直 & $\frac{140}{253}$ & \\
\hline
\end{tabular}

環境保全活動之は, 公園や樹林、農地, 河川I, 山岳地等における、無 自然教室, 動植物の調查, 外来生物の除去, 登山道整備などの活動とした。

太字・二重下線は, 選択肢で最も回答者の多い項目を示す。

下線ば択以上の場合に、2 2 2番目に多い回答の項目を示す。 


\section{3. 結 果}

（1）基本属性・登山経験・環境保全活動経験

回答者は 408 人であったが，そのうち「ライチョウ 目撃の有無」「ライチョウに関する知識」の設問にす心゙ て回答した回答を有効とし，有効回答者数は男性 288 名，女性 104 名の 393 名であった（回収率 85.8\%)。

表一 1 に単純集計の結果を示す。回答時期は 10 月 (57.5\%) が最も多く，7月 (34.9\%)，5月（7.6\%) の順である。年代は 50 代が $24.8 \%$ と最も多く, 次い で 40 代が $24.6 \% ， 60$ 代が $22.0 \%$ で 40 ６0 代が 7 割 であった。性別は男性が $73.5 \%$ と多い。居住地は，笹 ヶ峰登山口から $50 \mathrm{~km}$ 以内の地域 (新潟・長野・群馬・ 富山) に居住する人 (以下, 近隣居住者と記す) が $47.6 \%$, $50 \mathrm{~km}$ 以遠の地域に居住する人（以下，遠方居住者と 記す）が $52.4 \%$ あった。既婚者が $66.4 \%$ あ゙った。 収入は，200 万円未満が 4.1\%，200 400 万円未満が $21.4 \% ， 400 ６ 00$ 万円未満が 24.4\%，600８00 万円 未満が $17.0 \%$ ， 800 万円以上が $20.9 \%$ であった。登山 歴は, $5 \sim 10$ 年が $35.1 \%$ で, 次いで 20 年以上のベテラ ン登山者が $27.2 \%$ であった。 1 年の登山日数は 10 回以 上が $41.5 \%$ と最も多い。環境保全活動経験は，無が

$72.8 \%$ と多かった。

\section{(2) ライチョウとの関係}

ライチョウとの関係について表-1 下部に示す。ラ イチョウ目撃経験について，目撃したことのある登山 者が 79.6\%であった。一方，ライチョウとの能動的な 関わりについて，関わりがある登山者は $25.8 \%$ と少な い。ライチョウの知識について，ライチョウが絶滅危 惧種であると認知している登山者は 89.9\%であった。 また，ライチョウが火打山に生息していることを認知 していた登山者は 72.4\%であったが，火打山のライチ ヨウがほかの山域の個体群のなかで最小であることを 認知しているのは $31.4 \%$ と低かった。調査ツアーに参 加意思を有寸る登山者は，35.6\%と低かった。

\section{（3）調査ツア一への参加意思の有無による比較}

表-2 に調査ツアーへの参加意思の有無によって分 けた 2 群の集計結果を示す。基本属性では収入のみが 全体（表-1）との回答傾向に差が認められる項目で あるが，2 群に統計的な差は認められなかった。登山 経験にも有意な差が認められなかった。環境保全活動 経験の有無については 2 群で差が認められ，「無」群 に比べ有」群のほうが経験を有することが示された $(\mathrm{p}<0.05)$ 。ライチョウ目撃経験の有無では, 2 群の差 は認められなかった。ライチョウへの能動的な関わり の有無では，各質問項目では差が認められた（ $<<0.05$ 〜0.01)。さらに，いずれかの関わりを有する者をまと めると，全く関わりの無い者と比べ，参加意思を有し ていることが示された $(p<0.001)$ 。最後に，ライチョ ウに関する知識では, 絶滅危惧種であることの認知と, 火打山のライチョウ個体群が国内最小集団であること の認知で, 有意な差が認められ ( $\mathrm{p}<0.01)$, ぞちらの項目でも「有」 群は「無」群よりも認知が高い傾向が示された。

以上から，2群の回答傾向は，全体の回答傾向（表一1）に比心 顕著な回答の違いは見られないが，調査ツアーに参加意思の有無 によって, 環境保全活動経験, ライチョウとの積極的関わり，絶 滅危惧種であることの認知，火打山のライチョウが最小の個体群 であることの認知で，この 2 群に差があることが認められた。
表－2 調査ツアーへの参加意思の有無による比較

\begin{tabular}{|c|c|c|c|c|}
\hline 参加意思の有無によ & 回答群 & $\begin{array}{c}\text { 「有」群 } \\
\mathrm{n}=140\end{array}$ & $\begin{array}{c}\text { 「無」群 } \\
\mathrm{n}=253\end{array}$ & $\begin{array}{r}\chi^{2} \\
\text { 検定 } \\
\end{array}$ \\
\hline 回答時期と回答者数 & 5月(残雪期) & $7.9 \%(11)$ & $7.5 \%(19)$ & \\
\hline & 7月(夏山期) & $40.7 \% \quad(57)$ & $31.6 \% \quad(80)$ & \\
\hline & 10月(紅葉期) & $51.4 \%(12)$ & $60.9 \% \quad(154)$ & \\
\hline 1. 基本属性 & & & & \\
\hline 1) 年代 & 10代 & $0.7 \%(1)$ & $1.2 \% \quad(3)$ & \\
\hline & 20 代 & $7.1 \%(10)$ & $6.4 \% \quad(16)$ & \\
\hline & 30 代 & $12.1 \%(17)$ & $17.5 \% \quad(\quad 44)$ & \\
\hline & 40代 & $25.0 \% \quad(\quad 35)$ & $24.3 \% \quad(61)$ & \\
\hline & 50代 & $26.4 \%(37)$ & $23.9 \% \quad(\underline{\underline{60}})$ & \\
\hline & 60代 & $23.6 \% \quad(33)$ & $21.1 \% \quad(53)$ & \\
\hline & 70代 & $5.0 \%(7)$ & $5.6 \%(14)$ & \\
\hline 2) 性別 & 男性 & $70.7 \%(\underline{\underline{99}})$ & $75.1 \% \quad(\underline{190})$ & \\
\hline & 女性 & $29.3 \% \quad(41)$ & $24.9 \% \quad(63)$ & \\
\hline 3) 居住地 & 近隣(新潟、長野、群馬、富 & $50.4 \% \quad(70)$ & $46.2 \% \quad(116)$ & \\
\hline & その他 & $50.4 \% \quad(70)$ & $\underline{54.6 \%} \quad(\underline{137})$ & \\
\hline 4) 配偶者 & 有 & $70.5 \% \quad(\underline{\underline{g}})$ & $\underline{64.9 \%} \quad(\underline{\underline{163}})$ & \\
\hline & 無 & $29.5 \% \quad(\quad 41)$ & $35.1 \% \quad(\quad 88)$ & \\
\hline 5) 収入 & 200万円未満 & $7.6 \%(10)$ & $2.8 \% \quad(\quad 6)$ & \\
\hline & 200万円以上, 400万円未 & $\underline{25.2 \%}(3.3)$ & $23.8 \% \quad(\quad 51)$ & \\
\hline & 400万円以上, 600 万円未 & $23.7 \% \quad(31)$ & $\underline{30.4 \% \quad(\underline{\underline{6}})}$ & \\
\hline & 600万円以上, 800 万円未 & $22.1 \% \quad(29)$ & $17.8 \% \quad(38)$ & \\
\hline & 800万円以上 & $21.4 \% \quad(\quad 28)$ & $\underline{25.2 \%} \quad(\quad \underline{54})$ & \\
\hline . 登山経験 & & & & \\
\hline 1) 登山歴 & 1年未満 & $1.5 \% \quad(\quad 2)$ & $3.3 \% \quad(\quad 8)$ & \\
\hline & 1 2 2年 & $4.4 \% \quad(6)$ & $7.0 \% \quad(\quad 17)$ & \\
\hline & 3〜4年 & $11.7 \%(16)$ & $14.8 \% \quad(\quad 36)$ & \\
\hline & 5 10年 & $43.1 \% \quad(\quad 59)$ & $32.4 \% \quad(79)$ & \\
\hline & 11 20年 & $10.2 \% \quad(14)$ & $19.3 \% \quad(\quad 47)$ & \\
\hline & 21 年以上 & $\underline{30.7 \%} \quad(\quad \underline{42})$ & $\underline{26.6 \%} \quad(\underline{65})$ & \\
\hline 2）1年の登山頻度 & 1回以下 & $4.3 \%(6)$ & $1.6 \%(4)$ & \\
\hline & 2 3回程度 & $17.9 \% \quad(\quad 25)$ & $13.9 \%(35)$ & \\
\hline & 4 5回程度 & $20.7 \% \quad(29)$ & $17.1 \% \quad(\quad 43)$ & \\
\hline & 6 10回程度 & $22.9 \% \quad(\quad 32)$ & $21.5 \% \quad(\quad 54)$ & \\
\hline & 10回以上 & $34.3 \% \quad(48)$ & $45.8 \% \quad(115)$ & \\
\hline & 食の有無 & & & \\
\hline & 有 & $\begin{array}{rr}34.5 \% & (48) \\
\mathbf{6 5 . 5 \%} & (91)\end{array}$ & $\begin{array}{l}22.6 \%(57)- \\
77.4 \%(195)+\end{array}$ & \\
\hline 撃 & D有無 & $65.5 \% \quad($ & $(195)+$ & \\
\hline & $\begin{array}{l}\text { 有 } \\
\text { 無 }\end{array}$ & $\begin{aligned} 81.4 \% & (114) \\
18.6 \% & (26)\end{aligned}$ & $\frac{83.4 \%}{16.6 \%}\left(\begin{array}{l}211) \\
142)\end{array}\right.$ & \\
\hline
\end{tabular}

6. ライチョウに関する知識

1)ライチョウが絶滅危惧種で 1)講演会に参加したことがある

2)調査講習会に参加した ことがある

3)WEBサイト, SNSなどで情報を チェックしたことがある

4) 書籍を読んだことがある

5)グッズを持っている

上記1)〜5)のいずれかの 関わりの有無 あることの認知

2)ライチョウが火打山に生息 していることの認知

\section{りの有無}

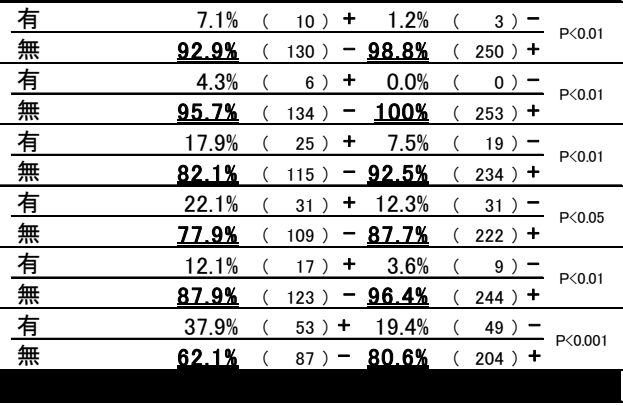

知っている $\quad \underline{95.7 \%}(134)+\underline{86.6 \%}$ ( 219) - $\mathrm{P}<0.0$

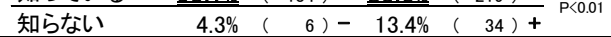
知っている $\quad \underline{77.1 \%} \quad(108) \quad \underline{70.0 \%} \quad(177)$ $\begin{array}{llllll}\text { 知らない } & 22.9 \% & (32) & 30.0 \% & (76)\end{array}$

3) 火打山のライチョウ個体群が国 知っている $42.1 \% \quad(\quad 59)+25.3 \%$ ( 64$)-{ }_{\mathrm{P}}<0.01$ 内最小集団であることの認知 知らない $\quad \underline{57.9 \%}(81)-\underline{74.7 \%}(189)+{ }^{\mathrm{P}}<0.01$ ()内の数字は回答者数を示す。太字·二重下線は, 選択肢で最も多い回答数の項目を示す。

下線は3択以上の場合に, 2番目に多い項目を示す。

の塗りつぶしは, 全体(表一1)の回答傾向と異なる項目を示す

残差分析で, $p<0.05$ となり, 有意差が認められた部分に「十」「一」を記した。「十」は有意に回答が多いことを示しており,「一」は 有意に回答が少ないことを示している。

\section{4. 考察}

本研究では，高山帯における市民参加型調査に参加意思を有す る登山者と無い登山者の比較から，その特徴を明らかにした。

本研究結果からも，これまで報告されてきた市民参加型調査に 参加意思を有する者の特徴として挙げられていた, 環境保全活動 経験, 保全対象への知識で差が認められた。環境保全活動経験に ついて先行研究では，環境保全活動を経験している人は，他の保 全活動に対しても参加意思を示すとされている 4)。本研究でも， 
調査ツアーに参加意思を有する者は，すでに環境保全活動経験が あることが示された。このことから, 高山帯の調査ツアーの参加 者募集は，すでに保全活動を実施している集団に対して募集案内 する有用性が示唆される。さらに, 西村11)の「防除活動への参加 には，防除対象となる外来種に関する知識が影響を及ぼす」とい う指摘がある。ライチョウへの積極的な関わりおよびライチョウ への知識を有する者は，保全対象種であるライチョウに対する興 味・関心がすでにあるため，参加意思を示したと考えられる。こ の結果は，駆除対象種だけでなく，保全対象種でも知識が保全活 動への参加意思に影響することを示唆するといえる。

一方，これまで報告されてきた市民参加型調査に参加意思を有 する者の特徵とされる，年代，性別，居住地，目撃経験での差が 認められなかった。これらの要因を考察すると，まず年代につい て先行研究では, 市民参加型調査に参加意思を有する人の特徵と してと，高齢であることを挙げている研究 3) と若年層であること を挙げている研究 4)の双方が存在する。次に性別について先行研 究では，絶滅危惧種の保護活動に参加意思のある人は，女性が多 いとされている 4)。しかし, 本研究では参加意思の有無と年代お よび性別との間には差が認められなかったことから，登山者から 調査ツア一の参加者募集をする場合には，年代や性別によってプ ログラム内容を考慮する必要が少ないと考えられる。居住地から 活動場所までの距離が遠く, 費用がかかる場合, 保全活動への参 加をためらう要因となることが指摘されている ${ }^{12) 。 ト ラ ヘ ゙ ル コ ス ~}$ 卜法の考え方 14)を適用寸れば, 居住地からの活動場所の距離が離 れていれば，旅費等の費用負担が大きくなるといえる。しかし， 本研究では居住地から火打山までの距離と参加意思の有無に関連 性は認めらなかったことから，高山帯の調査ツアーでは居住地と 活動地との距離が参加意思の阻害要因になりにくいと考えられ, 居住地から遠方で行われる調査ツアーであっても参加の可能性が あることが示唆される。また, 目撃経験について先行研究では, 絶滅危惧種の保護活動に参加意思のある者は，その種を目撃した ことがある者が多いとされる11)。しかし，本研究では参加意思に

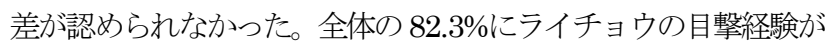
あることから，登山者がライチョウを目撃することは珍しいこと ではないといえる。一方で, ライチョウが絶滅危惧種であること の認知も全体で 89.8\%と高いが，「有」群と「無」群で差が認め られた。さらに，ライチョウと積極的関わりを持っている者は全 体の $26.0 \%$ と低いが，関わりを有することは参加意思に影響する ことが示された。このことから, 絶滅危惧種の目撃自体は珍しく なくとも, 絶滅危惧種に関心をもち, その状況を理解しているこ とが市民参加を促すためには重要であることが示唆される。

最後に, 収入には全体と 2 群の回答で唯一異なる傾向がみられ た。先行研究では世帯収入が高い者が環境保全活動に参加する傾 向が示されている 15)。本研究では, 統計的な有意差は認められな かったが，収入は「有」群は「無」群に比べ収入が低、傾向がみ られる。そのため, 収入と環境保全活動への参加意思の関係を議 論するには, より詳細な検討が必要と考えられる。

以上のように, 調査ツアーに参加意思を有する登山者の特徵は, 環境保全活動経験を有することやライチョウとの積極的な関わり を有することである。さらに, 先行研究の環境保全活動の参加者 とは異なる特徴も示されたことから, 高山帯の調査ツアーの参加 者募集では登山者以外が行う環境保全活動とは異なるアプローチ を検討しなければ，継続的に参加者を集めることは難しいと考え られる。

\section{5. まとめ}

高山帯での市民参加型調査の参加者を確保するには, 登山者の 属性を考慮したうえで，まずは保全対象に対する認識や関心を高
める機会を作ることが重要と考えられる。例えば，ライチョウの ような保全対象が生息する山域では，登山口や山小屋などで登山 者に向けてライチョウとその実情に関する情報提供を充実させる ことで認知度を高まりが，調査ツアーのような市民参加型保全を 実現するための下地作りとなることが期待される。さらに，山小 屋での宿泊や登山ツアーでは，ライチョウに関するインタープリ テーションを義務付けることで，積極的にライチョウ保全ひいて は山岳環境保全への理解を高めることも期待される。このように, 登山者が活動する地域の保全に直接寄与できる調査ツアーへの参 加を促すためには，段階的な市民参加型保全活動の仕組みづくり が求められる。

謝辞：本研究の遂行にあたり，筑波大学自然地域計画研究室の皆 さま，妙高市の関係者各位に多大なるご協力をいただきました。 この場を借りて，深く感謝申し上げます。

\section{補注及び引用文献}

1）環境省（2012）：生物多様性国家戦略 2012-2020一豊功自然共生社 会の実現に向けたロードマップ：

http://www.biodic.go.jp/biodiversity/about/initiatives/files/2012-2020 /01_honbun.pdf (2012/9/28 公開, 2018/9/25 閲覧)

2）環境省生物多様性センター (2014)：モニタリングサイト 1000 高山 帯調查一重要生態系監視地域モニタリング推進事業一2008〜2012 年 度とりまとめ報告書 :

http://www.biodic.go.jp/moni1000/findings/reports/pdf/h20-h24_alpi n_zone.pdf（2014/7 公開，2018/9/25 閲覧)

3) Kobori, H., Dickinson, J. L., Washitani, I., Sakurai, R., Amano, T., Komatsu, N., Kitamura, W., Takagawa, S., Koyama K., Ogawara, T. and Miller-Rushing, A. J. (2015) : Citizen science a new approach to advance ecology, education, and conservation: Ecological Research 31,1-19

4）本田裕子（2014）：保護活動に参加意思のある住民の特徴ーツシマヤ マネコ保護活動を対象にして:大正大学人間環境論集, 第 1 号, 57-63

5）高瀬唯・古谷勝則・櫻庭晶子（2014）：市民と緑地保全活動団体の意 識差からみる保全活動の参加促進課題: ランドスケープ研究, 77(5), $553-558$

6）小川結衣・武正憲・佐方啓介・長野康之 (2017) : 火打山における 1 時 間当たりの発見頻度(SPH)を用いたライチョウ調査ツアー実施時期及 ひ時間帯の検討 : 環境情報科学, 46(2), 71-76

7）環境省長野自然環境事務所（2014）: 第一期ライチョウ保護増殖事業 実施計画:

https://www.env.go.jp/press/files/jp/24426.pdf(2014/4 公開, 2018/9/25 閲覧)

8） 中村浩志・北原克宣・所洋一 (2003) : 火打山におけるライチョウの なわばり分布と生息個体数 : 信大志賀研究業績, $40 \mathrm{pp}$

9）小川結衣・武正憲・神宮翔真・長野康之・佐方啓介（2017）：高山帯 における絶滅危惧種ライチョウの専門家調査と登山ツアーによる市民 調查の特徵比較 : 環境情報科学学術研究論文集 $31,269-274$

10）国際自然環境アウトドア専門学校（2014）: 平成 25 年度グリーンワ 一カ一事業 頸城山系ライチョウ個体群生息状況把握調査事業 報告書, $36 \mathrm{pp}$

11）西村武司（2014）: 琵琶湖周辺における市民ボランティアによる侵略 的外来種の防除活動一の参加要因: 環境情報科学 学術研究論文集 28 , 297-302

12）岡本卓也・藤原武弘 (2015) : 登山行動に関する社会心理学的研究 登 山動機の構造とその変遷: 藤原武弘教授退職記念号, 関西学院大学社 会学部紀要, $120,167-180$

13）高瀬唯・古谷勝則（2013）: 大学生の意識から見た緑地保全活動の参 加促進課題と課題解決の優先順位：ランドスケープ研究，76(5), $717-722$

14）栗山浩 ・柘植隆宏・庄子康 (2013) : 初心者のための環境評価入門, 勁草書房, $287 \mathrm{pp}$

15）青柳みどり (1995) : 環境保全活動を担う人々:環境社会学研究, (1), 145-160 